Vol 1 No 1 Desember 2019

ARTIKEL PENELITIAN

\title{
IDENTIFIKASI BAKTERI PADA JAJANAN DI SEKOLAH DASAR NEGRI 060908 TEGAL SARI MANDALA II KECAMATAN MEDAN
}

\author{
Atikah Hanum ${ }^{1}$, Annisa ${ }^{2}$ \\ ${ }^{1}$ Fakultas Kedokteran, Universitas Muhammadiyah Sumatera Utara \\ ${ }^{2}$ Bagian Mikrobiologi, Fakultas Kedokteran, Universitas Muhammadiyah Sumatera Utara \\ Email: atikahhaanum@gmail.com, annisa@umsu.ac.id
}

\begin{abstract}
Abstract: Foodborne disease is an illness caused by food or beverages that contain microorganisms or chemicals. One of the causes of foodborne diseases is snacks sold in schools. There are some bacterias that can cause foodborne disease such as Salmonella sp, Staphylococcus sp, Escherichia sp, and Shigella $s p$. This is a descriptive observational study, with cross-sectional design, using every sample from SDN 060809 Tegal sari Mandala II, Kecamatan Medan Denai. The result of this study is that there are many types of bacterias, such as Staphylococcus aureus, Escherichia coli, Enterobavter sp, Proteus sp, and Aerobacter aerogens on snacks. Every sample taken from SDN060908 was found to contain bacterias, but didn't exceed the specified limit. The most common bacteria is Enterobacter sp.
\end{abstract}

Keywords: Foodborne disease, identification of bacteria, snack, elementary school.

\section{PENDAHULUAN}

Foodborne disease adalah penyakit akibat makanan yang terkontaminasi oleh mikroorganisme atau toksin. Makanan yang telah terkontaminasi masuk ke dalam tubuh melalui proses pencernaan yang dapat menyebabkan penyakit, seperti gastroentritis, salmonellosis, dan demam tifoid. Ada beberapa bakteri yang menyebabkan foodborne disease, yaitu salmonella $s p$, staphylococcus sp, escherichia $s p$, shigella sp. ${ }^{1}$

Hasil Riset Kesehatan Dasar pada tahun 2013 tentang foodborne disease berdasarkan diagnosis tenaga kesehatan dan keluhan responden terdiri dari tifoid $2,2 \%$, hepatitis $1,2 \%$, dan diare $3,5 \%$. Kejadian ini terjadi pada anak usia sekolah (5-14 tahun), kejadian diare menempati terbanyak setelah usia balita dan lansia yaitu sebesar 9\%. Sedangkan di Sumatera Utara kejadian tifoid 2,7\%, hepatitis $1,9 \%$, dan diare $4,9 \%{ }^{2}$

Berdasarkan perkiraan data foodborne disease menurut WHO pada tahun 2015, diare yang disebabkan oleh foodborne disease juga menyebabkan 230.000 kematian. Escherichia coli 37.000 kematian,. Penyebab utama foodborne disease non-diare disebabkan oleh Salmonella typhi sebanyak 52.000 kematian. $^{3}$

Jajanan merupakan salah satu jenis makanan yang dikenal oleh masyarakat terutama pada anak sekolah. Pedagang jajanan keliling banyak yang menjajakan makanan disekitar lingkungan sekolah dan sebagian besar mengambil tempat diluar pagar sekolah sehingga mudah 
Vol 1 No 1 Desember 2019

dijangkau olehsiswa. Berbagai makanan siap saji yang ditawarkan dengan aneka rasa, bentuk dan warna yang mempunyai daya tarik pada anak sekolah dan tidak semua makanan yang dijajakan ini memenuhi persyaratan kesehatan. ${ }^{4}$

\section{METODE PENELITIAN}

Penelitian ini merupakan penelitian deskriptif observasional menggunakan desain potong lintang dengan mengambil semua jenis sampel jajanan di SDN 060809 Tegal Sari Mandala II, Kecamatan Medan Denai.

\section{HASIL PENELITIAN}

Pada penelitian ini sampel yang diujikan sebanyak lima sampel, sampel tersebut terdiri dari bakso kojek 1, tahu bakar, sosis goreng, telur gulung dan bakso kojek 2.

\section{Hasil Pertumbuhan Bakteri}

Untuk mengidentifikasi setiap bakteri yang tumbuh pada masingmasing media, media yang digunakan untuk mengidentifikasi bakteri pada ke lima sampel adalah media Mueller Hinton Agar, Mannitol Salt Agar, Eosin Methylene Blue Agar dan MacConkey Agar.

Distribusi sampel berdasarkan pertumbuhan bakteri pada masingmasing media dari ke lima sampel.

Tabel 1. Pertumbuhan Bakteri

\begin{tabular}{cccc}
\hline Media & + & - & n \\
\hline MHA & 5 & - & 5 \\
& $(100 \%)$ & & $(100 \%)$ \\
\hline MSA & 5 & - & $5(100 \%)$ \\
& $(100 \%)$ & & \\
\hline MCA & $3(60 \%)$ & 2 & 5 \\
& & $(40 \%)$ & $(100 \%)$ \\
\hline EMB & $3(60 \%)$ & 2 & $5(100$ \\
& & $(40 \%)$ & $\%)$ \\
\hline
\end{tabular}

Berdasarkan tabel 1, terdapat pertumbuhan koloni bakteri pada Mueller Hinton Agar sebanyak lima (100\%) sampel. Pada Mannitol Salt
Agar terdapat pertumbuhan sebanyak lima (100\%) sampel. Pada MacConkey Agar terdapat pertumbuhan bakteri sebanyak tiga (60\%) sampel, sedangkan yang tidak terdapat pertumbuhan bakteri sebanyak dua (40\%) sampel. Pada Eosin Methylene Blue Agar terdapat pertumbuhan koloni bakteri sebanyak tiga (60\%) sampel, sedangkan yang tidak terdapat pertumbuhan bakteri sebanyak dua (40\%) sampel.

\section{Hasil Pewarnaan Bakteri}

Pewarnaan Gram yang dilakukan menggunakan larutan gentian violet, lugol, alkohol dan safranin. Pewarnaan Gram dilakukan pada semua sampel penelitian. Hasil pewarnaan gram dapat dilihat mengunakan mikroskop dengan perbesaran 100x, hasil yang didapatkan yaitu sifat dan morfologi bakteri.

Tabel 2. Hasil Pewarnaan Bakteri

\begin{tabular}{ccc}
\hline Sampel & Gram & Bentuk \\
\hline Bakso & + dan - & Kokus dan \\
kojek 1 & & basil \\
Tahu & + dan - & Kokus dan \\
bakar & & basil \\
Sosis & + dan - & Kokus dan \\
goreng & & basil \\
Telur & + dan - & Kokus dan \\
gulung & & basil \\
Bakso & + dan - & Kokus dan \\
kojek 2 & & basil \\
\hline
\end{tabular}

Berdasarkan tabel 2, hasil dari pewarnaan bakteri pada ke lima sampel tersebut terdapat bakteri gram positif dan gram negatif. Dari hasil pemeriksaan morfologi bakteri pada ke lima sampel terdapat morfologi bakteri kokus dan basil.

\section{Hitung Jumlah Koloni}

Hasil uji bakteriologis dari penghitungan jumlah bakteri dengan colony couter pada masing-masing sampel. 
Vol 1 No 1 Desember 2019

Tabel 3. Hitung Jumlah Koloni Bakteri

\begin{tabular}{ccc}
\hline Sampel & $\begin{array}{c}\text { Jumlah } \\
\text { koloni } \\
\text { (CFU/ } \\
\text { gram) }\end{array}$ & Keterangan \\
\hline $\begin{array}{c}\text { Bakso } \\
\text { kojek 1 }\end{array}$ & $0,6 \times 10^{3}$ & - \\
Tahu & $2,5 \times 10^{3}$ & - \\
bakar & & \\
$\begin{array}{c}\text { Sosis } \\
\text { goreng }\end{array}$ & $0,45 \times 10^{3}$ & - \\
Telur & $0,2 \times 10^{3}$ & - \\
gulung & & \\
Bakso & $1 \times 10^{3}$ & - \\
kojek 2 & & \\
\hline
\end{tabular}

Keterangan :

CFU /gram =Colony Form Unit

(-) : Tidak melebihi ambang batas

Berdasarkan tabel 3, didapatkan bahwa ke lima sampel yang telah diuji tidak melebihi ambang batas. Menurut keputusan dari Dirjen POM No 03726/B/SK/VII/89 bahwa batas maksimum bakteri pada makanan adalah $10^{4} \mathrm{CFU} / \mathrm{gram}$. Dari hasil tabel diatas, dapat disimpukan bahwa tahu bakarmemiliki jumlah koloni terbanyak yaitu 2,5 x $10^{3} \mathrm{CFU} / g r a m$ dibandingkan sampel yang lain. Sedangkan telur gulung memiliki jumlah koloni yang paling sedikit yaitu $0,2 \times 10^{3} \mathrm{CFU} /$ gram.

\section{Hasil Uji IMViC}

Kriteria dilakukannya uji IMViC pada penelitian ini yaitu bakteri yang bersifat gram negatif, bentuk basil dan kokus. Uji IMViC yang dilakukan terdiri dari Indole, Methyl Red, TSI dan Simmon Citrat.
Tabel 4. Hasil Uji IMViC

\begin{tabular}{|c|c|c|c|c|c|}
\hline \multirow[t]{2}{*}{ Sampel } & \multicolumn{4}{|c|}{ Uji Biokimia Uji Biokimia } & \multirow{2}{*}{$\begin{array}{c}\text { Genus } \\
\text { Bakte } \\
\text { ri }\end{array}$} \\
\hline & Indole & MR & TSIA & $\begin{array}{c}\text { SC } \\
\text { A }\end{array}$ & \\
\hline $\begin{array}{c}\text { Bakso } \\
\text { Kojek } 1\end{array}$ & + & - & $\mathrm{A} / \mathrm{AG}$ & + & $\begin{array}{c}\text { Entero } \\
\text { bacter } \\
s p\end{array}$ \\
\hline $\begin{array}{l}\text { Tahu } \\
\text { Bakar }\end{array}$ & + & - & $\mathrm{A} / \mathrm{AG}$ & + & $\begin{array}{c}\text { Entero } \\
\text { bacter } \\
\quad s p\end{array}$ \\
\hline $\begin{array}{l}\text { Sosis } \\
\text { Goreng }\end{array}$ & + & + & $\mathrm{A} / \mathrm{AG}$ & + & $\begin{array}{c}\text { Entero } \\
\text { bacter } \\
s p\end{array}$ \\
\hline $\begin{array}{c}\text { Telur } \\
\text { Gulung }\end{array}$ & - & + & $\mathrm{A} / \mathrm{A}$ & + & $\begin{array}{c}\text { Proteu } \\
\text { s sp }\end{array}$ \\
\hline $\begin{array}{c}\text { Bakso } \\
\text { Kojek } 2\end{array}$ & - & - & $\mathrm{A} / \mathrm{A}$ & - & $\begin{array}{c}\text { Aerob } \\
\text { acter } \\
\text { aerog } \\
\text { ens }\end{array}$ \\
\hline
\end{tabular}

Keterangan :

TSIA = Triple Sugar Iron Agar

SCA = Simmons Citrate Agar

MR = Methyl Red

$\mathrm{A}=$ Asam

$\mathrm{G}=\mathrm{Gas}$

Berdasarkan tabel hasil IMViC test pada ke lima sampel tersebut ditemukan beberapa bakteri yaitu, Enterobacter $s p$ ditemukan pada bakso kojek 1, tahu bakar dan sosis goring. Bakteri Proteus $s p$ pada telur gulung dan bakteri Aerobacter aerogans pada bakso kojek 2 .

\section{Jenis Bakteri}

Untuk mengetahui jenis bakteri pada setiap sampel maka dilakukan penanaman pada media agar yaitu penamanan pada Muellar Hinton Agar, MacConkey Agar, Eosin Methylene Blue Agar dan uji IMViC. Kemudian didapatkan hasil sebagai berikut : 
Vol 1 No 1 Desember 2019

Tabel 5. Jenis Bakteri

\begin{tabular}{ccc}
\hline $\begin{array}{c}\text { Jenis } \\
\text { Bakteri }\end{array}$ & $\begin{array}{c}\text { Jumlah } \\
\text { pertumbuhan } \\
\text { bakteri }\end{array}$ & $\%$ \\
\hline $\begin{array}{c}\text { Staphylo } \\
\text { coccus } \\
\text { aureus }\end{array}$ & 5 & $100 \%$ \\
$\begin{array}{c}\text { Escheri } \\
\text { chia coli } \\
\text { Entero }\end{array}$ & 3 & $60 \%$ \\
bacter sp \\
$\begin{array}{c}\text { Proteus } \\
\text { sp }\end{array}$ & 3 & $60 \%$ \\
$\begin{array}{c}\text { Aero } \\
\text { bacter } \\
\text { aerogens }\end{array}$ & 1 & $60 \%$ \\
\hline
\end{tabular}

Berdasarkan tabel 5 terdapat berbagai macam jenis bakteri yaitu Staphylococcus aureus terdapat pada ke lima sampel yaitu, bakso kojek 1, tahu bakar, sosis goreng, telur gulung dan bakso kojek 2. Bakteri Escherichia coli dan Enterobacter sp terdapat pada tiga sampel yaitu bakso kojek 1, tahu bakar dan sosis goreng. Bakteri Proteus sp terdapat pada telur gulung dan bakteri Aerobacter aerogens terdapat pada bakso kojek 2.

Berdasarkan penelitian lain yang dilakukan oleh Risna dan San Garry tahun 2015 menyatakan bahwa seluruh sampel jajanan SD terdapat cemaran bakteri, jumlah koloni bakteri pada beberapa sampel melebihi ambang batas normal yang ditetapkan Dirjen BPOM artinya tidak layak untuk dikonsumsi. Dan hasil uji biokimia terhadap koloni pada media EMB menunujukkan adanya bakteri famili Enterobactericeae dan beberapa genus sehingga terdapat beberapa perbedaan reaksi.Pada penelitian ini jumlah koloni tidak melebihi ambang batas, dan bakteri yang ditemukan merupakan salah satu dari famili Enterobactericeae. ${ }^{5}$

Berdasarkan penelitian yang dilakukan Rahmawita et al tahun 2018 menyatakan bahwa pemeriksan pada jajanan anak sekolah dasar di Koto
Tangah, Padang ditemukan bakteri Escherichia coli, Staphylococcus aureus dan bakteri jenis lain. Adanya bakteri pengkontaminan dalam makanan dapat menyebabkan keracunan makanan karena bakteri tersebut menghasilkan toksin, walaupun tidakmenimbulkan penyakit tetap akan menurunkan kualitas pangan jajanan anak sekolah tersebut. Pada penelitian yang dilakukan ditemukan bakteri yang sama yaitu, bakteri Escherichia coli dan Staphylococcus aureus. ${ }^{6}$

Penelitian lain yang dilakukan oleh A.M. Bukar et al pada tahun 2015 tentang keamanan bakteriologis dari beberapa makanan ringan yang yang dijual di Maiduguri, Nigeria. Pada kios lokal ditemukan jumlah koloni bakteri tertinggi terdapat pada daging yaitu $4 \times$ $10^{3} \mathrm{CFU}$, roti $6 \times 10^{3} \mathrm{CFU}$ dan donat $11 \times 10^{3}$ CFU. Dari hasil identifikasi bakteri ditemukan beberapa bakteri yaitu, Staphylococcus epidermidis, Bacillus subtilis, Staphylococcus aureus dan Corynebacteria speices. Namun pada penelitian ini hanya bakteri Staphylococcus aureus yang ditemukan dan bakteri yang lainnya tidak ditemukan. ${ }^{7}$

Dari hasil penelitian B.O.Oghene et al tahun 2014 menyimpulkan bahwa sebanyak 25 sampel makanan yang dibeli secara acak dari lima pedagang berbeda di pasar utama Ogbete, Enugu. Ditemukan semua sampel makanan yang disaring memiliki tingkat pertumbuhan bakteri yang bervariasi mulai dari $1,0 \mathrm{x}$ $10^{5}$ hinga $3,0 \times 10^{6} \mathrm{CFU}$. $90 \%$ dari makanan sampel memiliki jumlah bakteri di atas batas yang dapat diterima $\left(10^{4} \mathrm{CFU}\right)$ dan $10 \%$ dari sampel memiliki jumlah bakteri kurang dari $\left(<10^{4}\right.$ CFU). Enam spesies bakteri diisolasi dari makanan sampel yaitu Staphylococcus arueus, Bacillus cereus, Vibrio spp, Salmonella sp, Escherichia coli dan Shigella sp. Pada penelitian ini jumlah pertumbuhan koloninya tidak melebihi ambang batas. ${ }^{8}$ 
Vol 1 No 1 Desember 2019

Berdasarkan penelitian I Made Djaja pada tahun 2008 menyatakan bahwa kontaminasi bakteri pada tempat pengelolaan makanan rata-rata adalah kontaminasi bahan makanan 40,0\%, kontaminasi air $12,9 \%$, kontaminasi makanan matang $7,5 \%$, kontaminasi pewadahan makanan $16,9 \%$, kontaminasi tangan 12,5\%, dan kontaminasi makanan disajikan $12,2 \%$. Suhu pemasakan rata-rata $99,5 \%$, lama pemasakan 20,6 menit, suhu penyimpanan $28,9^{\circ} \mathrm{C}, \quad$ lama penyimpanan 409,2 menit, dan suhu penyajian $28,7^{0}$ C. Namun pada penelitian ini tidak melakukan pemeriksaan kontaminasi bakteri pada tempat pengelolaan makanan. ${ }^{9}$

\section{KESIMPULAN}

Berdasarkan penelitian ini disimpulkan bahwa seluruh jajanan yang dijual di SDN 060908 Tegal Sari Mandala II, Kecamatan Medan Denai teridentifikasi adanya bakteri, namun tidak melebihi ambang batas yang telah ditentukan. Pewarnaan gram dari masing-masing sampel dijumpai bakteri yang bersifat gram positif dan negatif dengan bentuk bakteri kokus dan basil dan IMViC test pada masing-masing sampel dijumpai bakteri yang berbeda-beda, bakteri yang paling banyak dijumpai adalah Enterobacter sp.

\section{DAFTAR PUSTAKA}

1. Ryman Napirah M. Faktor-Faktor Perilaku Hidup Bersih Dan Sehat Yang Berhubungan Dengan Kejadian Food Borne Disease Pada Anak Di Sekolah Dasar Negeri (Sdn) Inpres 3 Tondo Kota Palu. $J$ Kesehat Tadulako Heal Tadulako J. 2015;1(2):1-78.

2. Badan Penelitian dan Pengembangan Kesehatan. Riset
Kesehatan Dasar (RISKESDAS) 2013. Lap Nas 2013. 2013:1-384. doi:1 Desember 2013

3. WHO. WHO Estimates of The Global Burden of Foodborne Diseases. Who. 2015:1-255. doi:10.1016/j.fm.2014.07.009

4. Puspitasari RL. Kualitas Jajanan Siswa di Sekolah Dasar. Seri Sains dan Teknol. 2014;2(1):52-56. eh. 2012;(1):134-142.

5. Putri RWA. Identifikasi Bakteri Eschericia Coli Dan Salmonella Sp Pada Jajanan Batagor Di Sekolah Dasar Negeri Di Kelurahan Pisangan, Cirendeu, Dan Cempaka Putih Kecamatan Ciputat Timur.; 2016.

6. In $\mathrm{S}$, Tangah $\mathrm{K}$, Padang $\mathrm{D}$, Sumatra W. Kualitas Jajanan Anak Sekolah Dasar secara Mikrobiologi di Kecamatan Koto Tangah, Padang, Sumatera Barat. 2018;10:102-106.

7. Bukar AM. Bacteriological Quality Assessment of Some Snacks In Fast Food Shop Within Maiduguri Metropolitan Council. 2018;(December 2015).

8. Oghene BO, Oyarekua MA, Edeh AN. Original Research Article Bacteriological status of commonly consumed foods and vegetables from food vendors in a market in Enugu, Nigeria. 2014;3(11):151-156.

9. Djaja IM, Lingkungan DK, Masyarakat FK, Indonesia U. Dari Tiga Jenis Tempat Pengelolan Makanan (TPM) di Jakarta Selatan. 2008;12(1):3641. 